\title{
Over-expression of TLR4-CD14, pro-inflammatory cytokines, metabolic markers and NEFAs in obese non-diabetic Mexicans
}

Cesar Octavio De Loera-Rodriguez', Vidal Delgado-Rizo², Anabell Alvarado-Navarro², Juan Manuel Agraz-Cibrian, Jorge E Segura-Ortega ${ }^{3}$ and Mary Fafutis-Morris ${ }^{2 *}$

\begin{abstract}
Introduction: Obesity is the world's most important public health problem. Adipose tissue contributes significantly to increase pro-inflammatory mediators whose cascade begins with the union of TLR4 to its microbial ligands (TLR: Toll Like Receptors). It has been reported recently that NEFAs (Non-Esterified Fatty Acids) bind to this receptor as agonists. The purpose of our study was to determine the levels of expression of TLR4-CD14, the pro-inflammatory cytokines, the metabolic markers and the NEFAs in a group of adult, non-diabetic obese Mexicans.

Method: A group of 210 adult middle-class Mexican non-diabetic obese patients was evaluated: 105 normal weight individuals, and 105 non-diabetic obese. On both groups, the following was tested in each patient: TLR4-CD14 receptors on monocytes in peripheral blood, inflammatory profile, HOMA-IR (Homeostasis Model Assessment-Insulin Resistance), NEFAs and each individual's anthropometric profile.

Results: Obesity is strongly associated with the expression of TLR4 (77\%, MFI (Mean Fluorescence Index) 7.70) and CD14 (86\% MFI 1.61) with 66\% double positives $(p=0.000)$. These figures contrast with those for the normal weight individuals that constituted the control group: TLR4 (70\% MFI 6.41) and CD14 (84\% MFI 1.25) with 59\% double positives. As for cytokine concentration, non- diabetic obese individuals vs the normal weight/thin, the numbers were: $\mathrm{IL}-1 \beta=2.0$ vs $2.5 \mathrm{pg} / \mathrm{ml}(p=\mathrm{NS}), \mathrm{IL}-6=36 \mathrm{vs} 28 \mathrm{pg} / \mathrm{ml}(p=0.030), \mathrm{IL}-8=27 \mathrm{vs} 27 \mathrm{pg} / \mathrm{ml}(p=\mathrm{NS}), \mathrm{IL}-10=8.4 \mathrm{vs} 6.8 \mathrm{pg} / \mathrm{ml}$ ( $p=\mathrm{NS}$ ), TNF- $\alpha=31 \mathrm{vs} 15 \mathrm{pg} / \mathrm{ml}(p=0.000)$ respectively. Insulin levels were $12.1 \mathrm{vs} 19.7 \mathrm{mcU} / \mathrm{ml}(p=0.000)$ and the NEFAs were much higher in the obese vs normal weight/thin individuals $(p=0.000)$.

Conclusion: Adipose tissue used to be thought of as mere storage of fats and energy, but it has been revealed to be an important neuro-immune-endocrine organ. Immune cells, stimulated by NEFAs, produce pro-inflammatory cytokines, which have a direct effect on oxidating radicals that directly target the release of noradrenalin. This in turn, reactivates the vicious cycle of low-grade chronic inflammation, as is now described in obesity.
\end{abstract}

Keywords: TLR4, NEFAs, Inflammatory cytokines, Obesity, Metabolic markers

\section{Background}

Obesity is a world-wide problem that increases rapidly and can now be considered pandemic. It is considered the main public health problem facing Mexico (ENSANUT 2012). Obese patients have been observed to suffer from chronic low-grade inflammation as a result of the increase in the mass of adipose tissue, which raises the production

\footnotetext{
* Correspondence: mfafutis@gmail.com

${ }^{2}$ Departamento de Fisiología, Centro Universitario de Ciencias de la Salud, Universidad de Guadalajara, Guadalajara, Jal, México

Full list of author information is available at the end of the article
}

of pro-inflammatory mediators under exogenous and/or endogenous stimulation [1-3].

Adipose tissue (AT) used to be considered only as reserve tissue for fat. It is now considered an endocrine organ capable of releasing hormones (adiponectin, leptin, resistin, cytokines, chemokines, etc.). Additionally, AT expresses specific receptors for these hormones and for other molecules. In persons of normal weight, the AT is structured with normal size adipocytes, with very little macrophage infiltration. Obese individuals, however, present with hypertrophied adipocytes and elevation of 
the number of macrophages, both of which contribute to low-grade systemic inflammation [4-6]. It is assumed that adipocyte hypertrophy and local hypoxia are two of the most important factors that contribute to the accumulation of macrophages in the AT of the obese $[7,8]$. The macrophages of the adipose tissue (ATM) of the obese subjects are often found arranged in "crown-like structure" (CLS) surrounding dead adipocytes [9].

The phenotype of macrophages divides into subsets pro-(M1) or anti-inflammatory (M2). M1 phenotypes or classically activated macrophages are induced by (lipopolyssacaride) LPS and TNF- $\alpha$ and they produce proinflammatory cytokines (IL-1, IL-6 y TNF- $\alpha$ ). IL-6 is a cytokine relased by macrophages stimulated by noradrenalin (NA) as part of the hypothalamus-hypophysis-adrenal axis. This in turn releases corticosterone, modulating the systemic inflammatory response. However, it has recently been demonstrated in obese rats that the levels of NA are increased and the feedback mechanism NA-IL-6 is disrupted, maintaining the levels of IL- 6 even in the presence of corticosterone [10]. Thermic shock protein Hsp-72 is also a stimuli for macrophages to release inflammatory cytokines from both normal weight and obese rats [11].

Phenotype M2 or alternately activated macrophages are induced by glucocorticoids, $\mathrm{LL}-4$ and IL-10 and they produce anti-inflammatory cytokines $[8,12-14]$. An intermediate phenotype has also been described that is similar to the anti-inflammatory M2 but also secretes great quantities of pro-inflammatory cytokines $[15,16]$. In obese rats, the increase in numbers of macrophages in the AT is similar to that which occurs in humans. In models of rodents with diet induced obesity, there is a change in the ATM phenotype from an M2-polarized state in lean tissue, to a polarized-M1 state in obese animals $[17,18]$.

In obesity, adipocytes can release pro-inflammatory mediators, such as quimiokine CC (CCL) -2 , TNF- $\alpha$ and NEFAs instead of leptin and adiponectine that promote insulin sensitivity in a normal state [19]. Adipose tissue, then, significantly contributes to systemic inflammatory processes $[20,21]$ and to insulin resistance and hyperinsulinemia. We therefore find a highly coordinated.

Association between inflammatory pathways and metabolism [22]. This suggests an association between macrophages and free fatty acids [23].

Toll receptors (TLRs) play a critical role in the induction of the innate immune response in mammals via recognition of molecular patterns associated to microbial pathogens [24-27]. We have so far cloned 10 TLRs in humans [28-33]. TLR ligands include lipopolysaccharide (LPS) for TLR4. TLR4 can be activated by non-bacterial agonists such as Hsp60, fibronectin, Taxol, cover proteins of syncytial respiratory virus and by NEFAs [34-39]. TLRs are type 1 transmembrane receptors characterized by the presence of extracellular repeating motifs rich in leucine and a cytoplasmic tail with a homologous domain to the receptor of IL-1 (TIR) that is required to activate the downstream signaling pathways that lead to the activation of nuclear NF-кB that in turn promotes the increase in pro-inflammatory cytokine production [40].

\section{Objective}

The purpose of this study was to determine the expression of TLR4-CD14 in peripheral mononuclear cells, proinflammatory cytokines, metabolic markers and NEFAs in the serum of obese non-diabetic mestizo Mexican adults.

\section{Materials and methods \\ Population characteristics}

This is an analytical, descriptive study that included 210 middle-class mestizo Mexican residents of Western Mexico. Of these, 105 were normal weigh individuals, 55 men and 50 women. The second group was also 105, 35 men and 70 women, made up of obese individuals that did not present acute, chronic or inflammatory illnesses, nor were they taking any kind of medication. They had all maintained stable weight for at least 6 months. One of the two groups was categorized as obese, with a Body Mass Index $(\mathrm{BMI}) \geq 30 \mathrm{~kg} / \mathrm{m}^{2}$; the other group had a BMI $\leq 24.99 \mathrm{~kg} / \mathrm{m}^{2}$ and was the control group, being of normal weight. The subjects in the obese group were nondiabetic and presented with normal levels of cholesterol. Table 1 shows the clinical, metabolic, and anthropometric characteristics of all the participants in the study.

All participants were volunteers and signed an informed consent form. The study was carried out in accordance with the Helsinki Declaration guidelines and with the official Mexican norms in place regarding health issues.

\section{Data and sample collection}

Anthropometric measurements were taken for each participant along with weight and obesity status. The Body Mass Index (BMI) was calculated using weight and body size $\left(\mathrm{kg} / \mathrm{m}^{2}\right)$.

\section{Anthropometric measurements}

All anthropometric measurements were taken by the same researcher to insure accuracy. Body Mass and size were measured using a commercial stadiometer at the Nuevo Leon Clinic \#220, in Mexico, with a scale close to $0.2 \mathrm{~kg}$ and $1.0 \mathrm{~cm}$, respectively. Skin fold measurements were made with a skin fold caliper (Slim Guide Calliper) according to the guidelines of the International Society for the Advancement of Kineanthropometry (ISAK). Waist/hip circumference was taken with a non elastic measuring tape in centimeters (KaWe CE, Kirchner und Welhelm, Germany), according to ISAK guidelines [41]. 
Table 1 Clinical metabolic and andtropometric characteristic of study subjects

\begin{tabular}{|c|c|c|c|}
\hline & $\begin{array}{l}\text { Non diabetic } \\
\text { obese } \mathrm{N}=105\end{array}$ & $\begin{array}{l}\text { Normal weight } \\
\mathrm{N}=105\end{array}$ & $\mathrm{t}$ student \\
\hline Gender (male/ female) & $35 / 70$ & $55 / 50$ & - \\
\hline Age (years) & $38.5 \pm 12.8$ & $33.4 \pm 13.4$ & 0.006 \\
\hline Weight (kg) & $93.4 \pm 17.2$ & $65.8 \pm 9.1$ & 0.000 \\
\hline BMI (kg/m2) & $34.7 \pm .4$ & $23.3 \pm 1.5$ & 0.000 \\
\hline Body fat mass (\%) & $37.3 \pm 6.5$ & $23.4 \pm 4.0$ & 0.000 \\
\hline WHI & $1.1 \pm 0.3$ & $0.8 \pm 0.9$ & 0.000 \\
\hline$A C(\mathrm{~cm})$ & $109.2 \pm 13.9$ & $83.4 \pm 9.6$ & 0.000 \\
\hline $\mathrm{HC}(\mathrm{cm})$ & $116.3 \pm 14.3$ & $98.2 \pm 8.2$ & 0.000 \\
\hline $\begin{array}{l}\text { Time whit their } \\
\text { weight (years) }\end{array}$ & $6.9 \pm 5.4$ & $6.4 \pm 4.5$ & 0.488 \\
\hline Glucose (mg/dl) & $107.2 \pm 9.70$ & $81.1 \pm 9.1$ & 0.000 \\
\hline Chlosterol (mg/dl) & $173.5 \pm 40.8$ & $161.7 \pm 35.3$ & 0.027 \\
\hline Triglycerides (mg/dl) & $168.5 \pm 139.5$ & $126.0 \pm 76.0$ & 0.007 \\
\hline LDL (mg/dl) & $100.2 \pm 36.1$ & $93.6 \pm 29.9$ & 0.149 \\
\hline $\mathrm{HDL}(\mathrm{mg} / \mathrm{dl})$ & $40.6 \pm 11.5$ & $43.1 \pm 10.3$ & 0.108 \\
\hline Insulin (mcU/ml) & $19.7 \pm 13.2$ & $12.1 \pm 3.4$ & 0.000 \\
\hline HOMA-IR & $5.3 \pm 3.7$ & $2.4 \pm 0.7$ & 0.000 \\
\hline NEFA (mEq/L) & $4.7 \pm 4.7$ & $0.3 \pm 0.21$ & 0.000 \\
\hline
\end{tabular}

Data are presented as mean \pm standard deviatior. $B M I$ : Body mass index; WHI: Waist-hip index; AC: Abdominal circumference; HC: Hip circumference; LDL: Low density lipoprotein; HDL: High density lipoprotein; NEFA: Non-esterified fatty acids.

\section{Body mass measurement}

Body fat percentage was estimated using an anthropometric equation for the general population [42]. For the general population $=0.465+0.180 *(\mathrm{~S} 7 \mathrm{SF})-0.0002406 *$ $(\mathrm{S} 7 \mathrm{SF})^{2}+0.0661 *$ (age), where S7SF is the sum of the skin folds of the chest, axila, tríceps, subscapular región, abdomen, suprailiac, and mid-thigh, in millimeters, and age is expressed in years. To determine body density, we used the Wilmore et al. equation, which for people active in sports is $1.0988-0.0005^{*}$ (S7SF), where S7SF is the sum of the skin folds from the chest, axilla (armpit), triceps, subscapular region, abdomen, suprailiac area, and caudal mid-thigh in millimeters [41]. Body fat was calculated using the Siri equation (Siri/body density) - 450 [43].

\section{Measurement of CD14 y TLR-4}

Blood samples were obtained after the signing of the informed consent form and were collected in test tubes with heparin to separate the mononuclear cells of peripheral blood (PBMC), and dry tubes to collect serum. The serum samples were stored at $-80^{\circ} \mathrm{C}$ until their use.

CD14 and TLR4 was measured with flow cytometry using anti-CD14 antibodies (eBioscience, San Diego, CA, USA) and anti TLR4-PE (eBioscience, San Diego, Ca,
USA). Appropriate isotope controls were used for each fluorochrome with irrelevant antibodies.

Monocyte population was identified based on size and granular characteristics in an EPICS XL-MCL flow cytometer (Beckman Coulter, Krefeld, Germany). A total of 10,000 CD14 + monocytes was read for each sample. The percentage of TLR4 + CD14+ monocytes was calculated from the analysis of the two fluorochromes (See Figure 1). Data was analyzed using FlowJo software (Arbol Star Inc., Ashland, Oregon, USA). Mean Fluorescence intensity (MFI) was determined subtracting the intensity of the geometric mean fluorescence from the sample control isotope.

\section{Metabolic parameters}

All subjects underwent the same 12 hour fasting conditions before testing. Total NEFA levels in serum were measured by enzymatic assay (Wako, Richmond, VA). Insulin levels were measured using an ELISA kit (Genway Biotech, Inc), and glucose levels were measured using a glucometer (active Accu-Chek, Roche).

\section{Cytokines}

Pro-inflammatory cytokines (IL-1 $\beta$, IL-6, IL-8 and TNF $\alpha$ ) and the anti-inflammatory profile (IL-10) were measured using ELISA MAX ${ }^{\mathrm{ms}}$ Deluxe Sets kits (BioLegend Inc, San Diego, CA), according to manufacturer's instructions.

\section{Statistics}

Statistical analysis was made using the SPSS v18.0 program and Excel 2010 software. Tests for significant differences were made, comparing obese to normal weight. Simple statistical comparisons were made using Student's "t" test. Differences were considered significant when $\mathrm{P}<0,05\left(^{*}\right)$. All results are presented as $+/-$ standard deviation $\mathrm{SD}$ from the mean.

\section{Results}

\section{Obesity and clinical and anthropometric characteristics}

The clinical and anthropometric characteristics were significantly greater in the obese $\tan$ in the normal weight subjects $(\mathrm{p}<0,001)$ (Table 1). Mean BMI in the obese group was $34.7+/-5.4 \mathrm{~kg} / \mathrm{m}^{2}$ and in the normal weight group, $23,3+/-1,5 \mathrm{~kg} / \mathrm{m}^{2}$ ( $\left.\mathrm{p}<0,000\right)$; percentage of fat mass was $37,3+/-6,5 \%$ vs $23,4+/-4 \%$ ( $<<0,000)$; waist circumference $109,2+/-13,9 \mathrm{~cm}$ vs $83.4+/-9.6 \mathrm{~cm}$ (p <0,000); glucose $107,2+/-9,7 \mathrm{mg} / \mathrm{dl}$ vs $81,08+/-$ 9,1 mg/dl ( $\mathrm{p}<0,000)$; triglycerides $168.5+/-139.5 \mathrm{mg} / \mathrm{dL}$ vs $126+/-76 \mathrm{mg} / \mathrm{dL}(\mathrm{p}<0,000)$; insulin 19,7+/- 13,2 $\mathrm{MCU} / \mathrm{ml}$ vs $12,1+/-3,4 \mathrm{MCU} / \mathrm{ml}(\mathrm{p}<0,007)$ and NEFA $4,7+/-4,7 \mathrm{mEq} / \mathrm{L}$ vs $0,25+/-0,21 \mathrm{mEq} / \mathrm{L}(\mathrm{p}<0,000)$, respectively. 


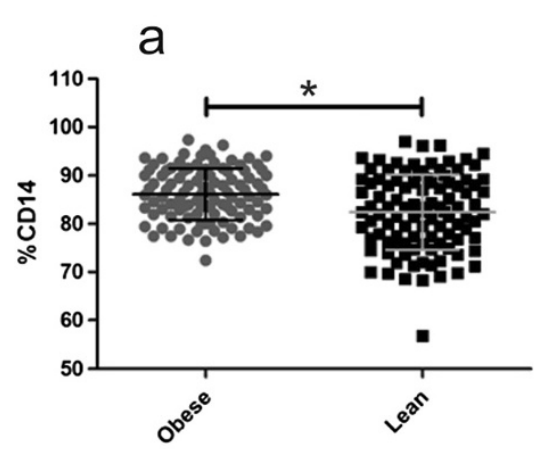

b
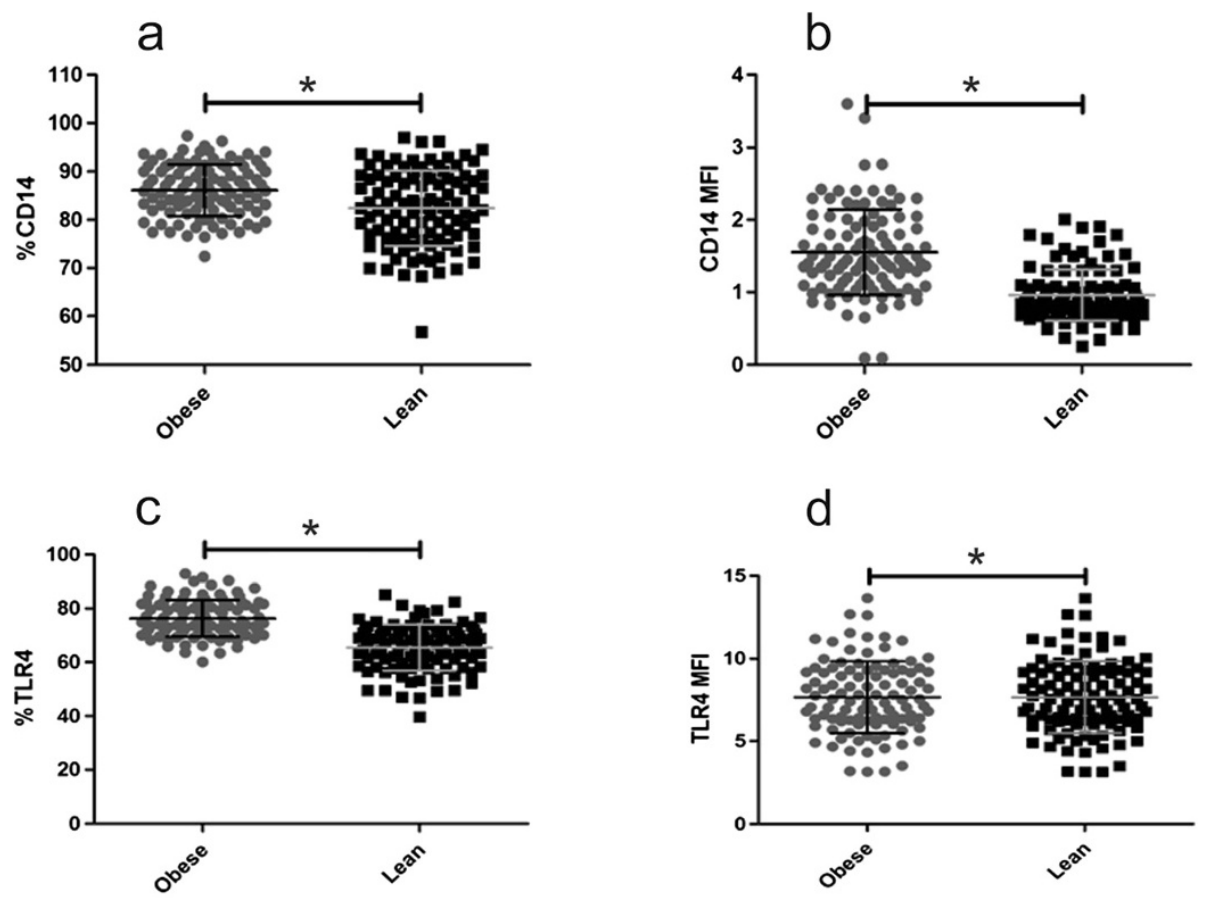

e

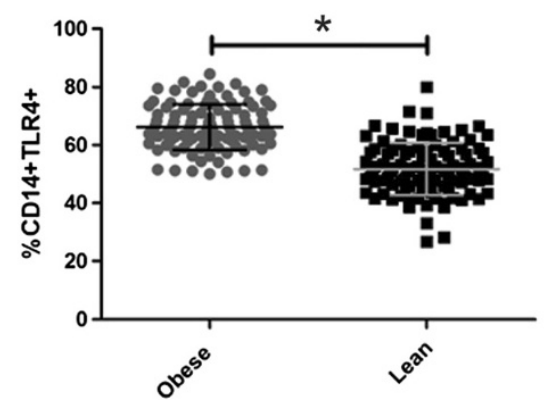

Figure 1 Percentage and IFM of expression TLR4 and CD14. The expression of TLR4/CD14 was more in obese then lean individuals. a) Percentage CD14 expression. b) CD 14 mean fluorescence index. c) Percentage TLR4 expression. d) TLR4 mean fluorescence index. e) Percentage of positive double expression CD14-TLR4. The graphs show the mean \pm SD of the results.

\section{TLR4-CD14 expression}

The percentage of TLR4 and CD14 expression in monocytes of peripheral blood and the Mean Fluorescence Index (MFI) was significantly greater in the obese $(p<0,05)$ than in the subjects of normal weight (Figure 1$)$.

\section{Inflammatory profile}

The concentration of IL- 6 and TNF $\alpha(36 \mathrm{pg} / \mathrm{ml}$ vs 31 $\mathrm{pg} / \mathrm{ml}$ ) in serum was greater in the obese and was statistically more significant in comparison to the individuals of normal weight $(28 \mathrm{pg} / \mathrm{ml}$ vs $15 \mathrm{pg} / \mathrm{ml})$, respectively ( $p<0,05)$. The concentration of IL-1 $\beta$ in serum, IL-8, and IL-10 were not statistically significant when comparing obese and non- obese individuals (Figure 2).

\section{Metabolic markers}

Insulin levels, HOMA-IR and NEFA measurements are the markers we used to determine the association between obesity and the role of the inflammatory process. The concentration levels of these three markers have been significantly greater $(\mathrm{p}<0,000)$ in the obese than in persons of normal weight. Insulin $19,7+/-13,2 \mathrm{mcU} / \mathrm{mL}$ vs $12,1+/-$ $3,4 \mathrm{mcU} / \mathrm{mL}$, HOMA-IR $5.3+/-3.7$ vs $2.4+/-0.7$ and NEFA $4,7+/-4,7 \mathrm{mEq} / \mathrm{L}$ vs $0.21+/-0.25 \mathrm{mEq} / \mathrm{L}$, respectively (Figure 3).

\section{Discussion}

Obesity is the consequence of an augment in adipose tissue, with accompanying alteration of the immune response, 


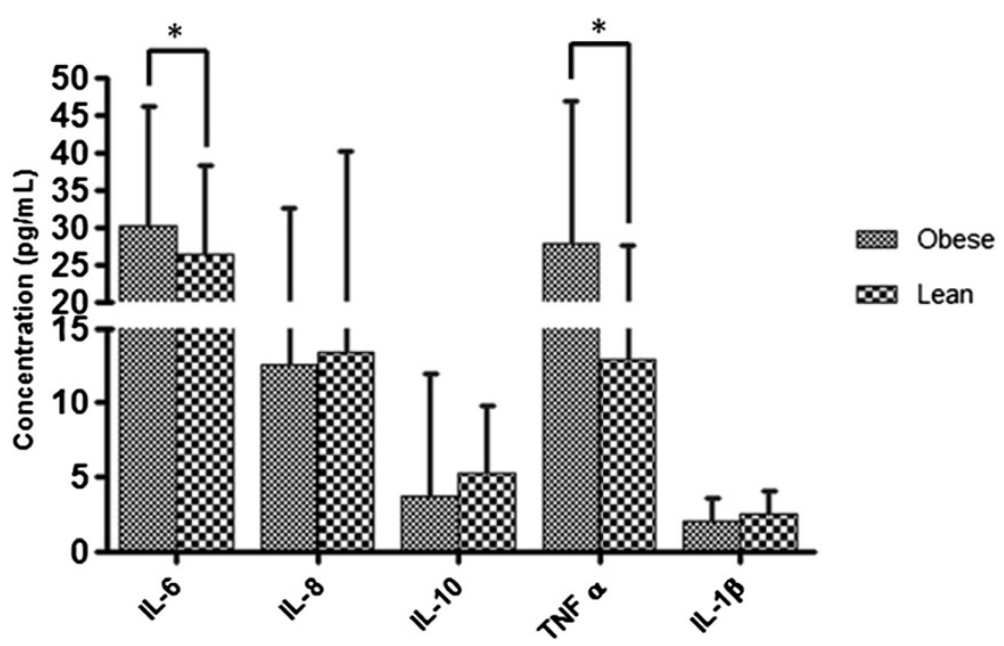

Figure 2 Serum cytokine concentration. The serum cytokine from lean and obese groups were measured by ELISA. Cytokines expressions are shown in $\mathrm{pg} / \mathrm{mL}$ for each group. Results expressed the cytokines levels on serum and are represented as means \pm SD values. A strong association of IL-6 and TNF-a with obesity was observed $\left({ }^{*} \mathrm{p}<0.05\right)$.

resulting in an increase in the number of macrophages in the AT, insulin resistance and hyperinsulinemia, elevated NEFA levels as well as elevated pro- inflammatory mediators (IL-1, IL-6 y TNF- $\alpha$ ) [44-46].

Our study found: greater percentage of TLR4-CD14 expression and mean fluorescence index in monocytes, along with elevated levels of IL- 6 and TNF $\alpha$ in obese adults compared to normal weight subjects. This data coincides with the work done by Ahmad et al. [47].

The patients in this study, although non-diabetic obese, presented insulin resistance, according to HOMA. The elevation of this hormone is an attempt to maintain the concentration of glucose within normal levels. But insulin resistance elevates NEFAs [48]. The obese patients in our study show NEFA levels 18 times higher than the normal weight individuals. NEFAs are TLR4 agonists that might be triggering a low-grade inflammatory response, as evidenced by the seric concentrations of TNF- $\alpha$ and IL-6 [23]. Delving deeper into the identification of the types of fatty acids that are being released will permit greater understanding of the pro-inflammatory/ metabolic feedback that we found in these patients. Adipose tissue maintains a proportion between saturated fatty acids, palmitic and stearic acids at $22 \%$, and monounsaturated oleic at $50 \%$. This proportion is maintained in the adipose tissue of both obese and normal weight

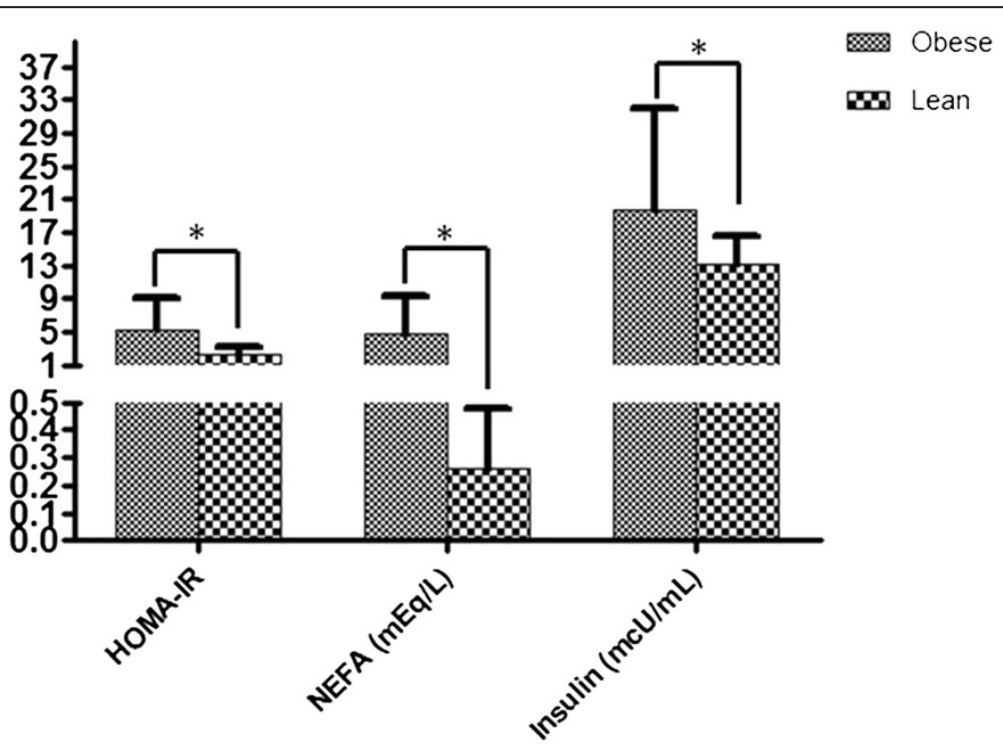

Figure 3 Determination of metabolic markers. The metabolic study reflected that in comparison to obese and lean individuals had significantly higher serum levels $\left({ }^{*} \mathrm{p}<0,000\right.$ ) of HOMA-IR, basal NEFAs (mEq/L), basal glycemia (mg/dL) (see Table 1) and basal insulin (mcU/mL). 
individuals [49]. It has been shown that long chain saturated fatty acids are the ones that produce the inflammatory response and they have the capacity to express TLR-4. and TLR-2 in monocytes in vitro which would explain, in part, the increased expression in the obese group.

Although the obese group were not diabetic, it would be interesting to do research in vitro with TLR-4 and TLR-2 induction since high levels of glucose of $270 \mathrm{mg} / \mathrm{dl}$, along with high NEFA concentrations, augment the induction effect of TLR-4, the release of Reactive Oxygen Species (ROS), and inflammatory cytokines in human monocytes in vitro [50]. On the other hand, it has been demonstrated that obese individuals maintain a state of constant stress mediated by the excess release of pro-inflammatory cytokines such as ROS, in addition to physiological stress, in which the neurotransmitter noradrenalin has a direct effect on the immune system via specific receptors that set up another vicious feedback cycle between the cells of the immune system, the endocrine and the central nervous system [51].

Conclusion: Adipose tissue used to be thought of as mere storage of fats and energy, but it has been revealed to be an important neuro-immune-endocrine organ. Immune cells, stimulated by NEFAs, produce pro-inflammatory cytokines, which have a direct effect on oxidating radicals that directly target the release of noradrenalin. This in turn, reactivates the vicious cycle of low-grade chronic inflammation, as is now described in obesity.

\section{Competing interests}

The authors declare that they have no competing interests.

\section{Authors' contributions}

MFM, VDR: Conceived and designed the experiment. COD, JAC, AAN: Performed the experiments: MFM, COD, VDR, JSO: Analyzed the data: MFM, VDR: Contributed reagents/materials/analysis tools: MFM, VDR, JAC: Wrote the paper. All authors read and approved the final manuscript.

\section{Author details}

'Doctorado en Ciencias Biomédicas, Guadalajara, Jal, México. ${ }^{2}$ Departamento de Fisiología, Centro Universitario de Ciencias de la Salud, Universidad de Guadalajara, Guadalajara, Jal, México. ${ }^{3}$ Servicio de Gastroenterología, Antiguo Hospital Civil de Guadalajara "Fray Antonio Alcalde", Guadalajara, Jal, México.

Received: 15 November 2013 Accepted: 16 November 2014

Published online: 29 November 2014

\section{References}

1. Wellen KE, Hotamisligil GS: Obesity-induced inflammatory changes in adipose tissue. J Clin Invest 2003, 112:1785-8.

2. Bastard J-P, Maachi M, Lagathu C, Kim MJ, Caron M, Vidal H, Capeau J, Feve $B$ : Recent advances in the relationship between obesity, inflammation, and insulin resistance. Eur Cytokine Netw 2006, 17:4-12.

3. Coppack SW: Pro-inflammatory cytokines and adipose tissue. Proc Nutr Soc 2001, 60:349-56.

4. Dandona P, Aljada A, Bandyopadhyay A: Inflammation: the link between insulin resistance, obesity and diabetes. Trends Immunol 2004, 25:4-7.

5. Weisberg SP, McCann D, Desai M, Rosenbaum M, Leibel RL, Ferrante AW: Obesity is associated with macrophage accumulation in adipose tissue. J Clin Invest 2003, 112:1796-808.

6. Cancello R, Henegar C, Viquerie N, Taleb S, Poitou C, Rouault C, Coupaye M, Pelloux V, Hugol D, Bovillot JL, Bouloumie A, Barbatelli G, Cinti S, Svensson
PA, Barsh GS, Zucker JD, Boudevant A, Langing D, Clement K: Reduction of macrophage infiltration and chemoattractant gene expression changes in white adipose tissue of morbidly obese subjects after surgery-induced weight loss. Diabetes 2005, 54:2277-86.

7. Trayhurn P: Hypoxia and adipose tissue function and dysfunction in obesity. Physiol Rev 2013, 93:1-21.

8. Dalmas E, Clément K, Guerre-Millo M: Defining macrophage phenotype and function in adipose tissue. Trends Immunol 2011, 32:307-14.

9. Cinti S, Mitchell G, Barbatelli G, Murano I, Ceresi E, Faloia E, Wang S, Fortier M, Greenberg AS, Obin MS: Adipocyte death defines macrophage localization and function in adipose tissue of obese mice and humans. J Lipid Res 2005, 46:2347-55.

10. Martín-Cordero L, García JJ, Hinchado MD, Ortega E: The interleukin-6 and noradrenaline mediated inflammation-stress feedback mechanism is dysregulated in metabolic syndrome: effect of exercise. Cardiovasc Diabetol 2011, 10:42.

11. Martín-Cordero L, García JJ, Hinchado MD, Bote E, Ortega E: Influence of exercise on NA- and Hsp72-induced release of IFNY by the peritoneal suspension of macrophages and lymphocytes from genetically obese Zucker rats. J Physiol Biochem 2013, 69:125-31.

12. Martinez FO, Helming L, Gordon S: Alternative activation of macrophages: an immunologic functional perspective. Annu Rev Immunol 2009, 27:451-83.

13. Sulahian TH, Högger P, Wahner AE, Wardwell K, Goulding NJ, Sorg C, Droste A, Stheling M, Wallace PK, Morganelli PM, Guyre PM: Human monocytes express CD163, which is upregulated by IL-10 and identical to p155. Cytokine 2000, 12:1312-21.

14. Gratchev A, Schledzewski K, Guillot P, Goerdt S: Alternatively activated antigen- presenting cells: molecular repertoire, immune regulation, and healing. Skin Pharmacol Appl Skin Physiol 2001, 14:272-9.

15. Zeyda M, Farmer D, Todoric J, Aszmann O, Speiser M, Györi G, Zlabinger GJ, Stulnig TM: Human adipose tissue macrophages are of an antiinflammatory phenotype but capable of excessive pro-inflammatory mediator production. Int J Obes (Lond) 2007, 31:1420-8.

16. Bourlier V, Zakaroff-Girard A, Miranville A, De Barros S, Maumus M, Sengenes C, Galitzky J, Lafontan M, Karpe F, Frayn KN, Bouloumie A: Remodeling phenotype of human subcutaneous adipose tissue macrophages. Circulation 2008, 117:806-15.

17. Lumeng CN, Bodzin JL, Saltiel AR: Obesity induces a phenotypic switch in adipose tissue macrophage polarization. J Clin Invest 2007, 117:175-84.

18. Nguyen MTA, Favelyukis S, Nguyen A-K, Reichart D, Scott PA, Jenn A, Liu-Bryan R, Glass CK, Neels JG, Olefsky JM: A subpopulation of macrophages infiltrates hypertrophic adipose tissue and is activated by free fatty acids via Toll-like receptors 2 and 4 and JNK-dependent pathways. J Biol Chem 2007, 282:35279-92.

19. Biswas SK, Mantovani A: Orchestration of metabolism by macrophages. Cell Metab 2012, 15:432-7.

20. Monteiro R, Azevedo I: Chronic inflammation in obesity and the metabolic syndrome. Mediators Inflamm 2010, 2010:1-10.

21. Fain JN: Release of inflammatory mediators by human adipose tissue is enhanced in obesity and primarily by the nonfat cells: a review. Mediators Inflamm 2010, 2010:1-20.

22. Milanski M, Degasperi G, Coope A, Morari J, Denis R, Cintra DE, Tsukumo TM, Anhe G, Amaral ME, Takahashi HK, Curi R, Oliveira HC, Carvalheira JB, Bordin S, Saad MJ, Velloso LA: Saturated fatty acids produce an inflammatory response predominantly through the activation of TLR4 signaling in hypothalamus: implications for the pathogenesis of obesity. J Neurosci 2009, 29:359-70.

23. Lee JY, Ye J, Gao Z, Youn HS, Lee WH, Zhao L, Sizemore N, Hwang DH: Reciprocal modulation of Toll-like receptor-4 signaling pathways involving MyD88 and phosphatidylinositol 3- kinase/AKT by saturated and polyunsaturated fatty acids. J Biol Chem 2003, 278:37041-51.

24. Akira S: Mammalian Toll-like receptors. Curr Opin Immunol 2003, 15:5-11.

25. Medzhitov R, Janeway CA: Innate immunity: the virtues of a nonclonal system of recognition. Cell 1997, 91:295-8.

26. Aderem A, Ulevitch RJ: Toll-like receptors in the induction of the innate immune response. Nature 2000, 406:782-7.

27. Akira S, Takeda K, Kaisho T: Toll-like receptors: critical proteins linking innate and acquired immunity. Nat Immunol 2001, 2:675-80.

28. Chuang TH, Ulevitch RJ: Cloning and characterization of a sub-family of human toll- like receptors: hTLR7, hTLR8 and hTLR9. Eur Cytokine Netw 2000, 11:372-8. 
29. Du X, Poltorak A, Wei Y, Beutler B: Three novel mammalian toll-like receptors: gene structure, expression, and evolution. Eur Cytokine Netw 2000, 11:362-71.

30. Rock FL, Hardiman G, Timans JC, Kastelein RA, Bazan JF: A family of human receptors structurally related to Drosophila Toll. Proc Natl Acad Sci U S A 1998, 95:588-93.

31. Takeuchi O, Kawai T, Sanjo H, Copeland NG, Gilbert DJ, Jenkins NA, Takeda K, Akira S: TLR6: A novel member of an expanding toll-like receptor family. Gene 1999, 231:59-65.

32. Chuang T, Ulevitch RJ: Identification of hTLR10: a novel human Toll-like receptor preferentially expressed in immune cells. Biochim Biophys Acta 2001, 1518:157-61.

33. Rhee SH, Hwang D: Murine TOLL-like receptor 4 confers lipopolysaccharide responsiveness as determined by activation of NF kappa B and expression of the inducible cyclooxygenase. J Biol Chem 2000, 275:34035-40.

34. Ohashi K, Burkart V, Flohé S, Kolb H: Cutting edge: heat shock protein 60 is a putative endogenous ligand of the toll-like receptor- 4 complex. $\mathrm{J}$ Immunol 2000, 164:558-61.

35. Okamura Y, Watari M, Jerud ES, Young DW, Ishizaka ST, Rose J, Chow JC, Strauss JF 3rd: The extra domain A of fibronectin activates Toll-like receptor 4. J Biol Chem 2001, 276:10229-33.

36. Kurt-Jones EA, Popova L, Kwinn L, Haynes LM, Jones LP, Tripp RA, Walsh EE, Freeman MW, Golenback DT, Anderson LJ, Finberg RW: Pattern recognition receptors TLR4 and CD14 mediate response to respiratory syncytial virus. Nat Immunol 2000, 1:398-401.

37. Lee JY, Sohn KH, Rhee SH, Hwang D: Saturated fatty acids, but not unsaturated fatty acids, induce the expression of cyclooxygenase-2 mediated through Toll-like receptor 4. J Biol Chem 2001, 276:16683-9.

38. Byrd-Leifer CA, Block EF, Takeda K, Akira S, Ding A: The role of MyD88 and TLR4 in the LPS-mimetic activity of Taxol. Eur J Immunol 2001, 31:2448-57.

39. Alexopoulou L, Holt AC, Medzhitov R, Flavell RA: Recognition of doublestranded RNA and activation of NF-kappaB by Toll-like receptor 3. Nature 2001, 413:732-8.

40. Medzhitov R, Preston-Hurlburt P, Janeway CA: A human homologue of the Drosophila Toll protein signals activation of adaptive immunity. Nature 1997, 388:394-7.

41. Knechtle B, Wirth A, Knechtle P, Rosemann T, Rüst CA, Bescós R: A comparison of fat mass and skeletal muscle mass estimation in male ultra-endurance athletes using bioelectrical impedance analysis and different anthropometric methods. Nutr Hosp 2011, 26:1420-7.

42. Ball SD, Altena TS, Swan PD: Comparison of anthropometry to DXA: a new prediction equation for men. Eur J Clin Nutr 2004, 58:1525-31.

43. Siri WE: Body composition from fluid spaces and density: analysis of methods. 1961. Nutrition 1993, 9:480-491. discussion 480, 492.

44. Kim F, Pham M, Luttrell I, Bannerman DD, Tupper J, Thaler J, Hawn TR, Raines EW, Schwartz MW: Toll-like receptor-4 mediates vascular inflammation and insulin resistance in diet-induced obesity. Circ Res 2007, 100:1589-96.

45. Lam TKT, van de Werve G, Giacca A: Free fatty acids increase basal hepatic glucose production and induce hepatic insulin resistance at different sites. Am J Physiol Endocrinol Metab 2003, 284:E281-290

46. Bunn RC, Cockrell GE, Ou Y, Thrailkill KM, Lumpkin CK, Fowlkes JL: Palmitate and insulin synergistically induce IL-6 expression in human monocytes. Cardiovasc Diabetol 2010, 9:73.

47. Ahmad R, Al-Mass A, Atizado V, Al-Hubail A, Al-Ghimlas F, Al-Arouj M, Bennakhi A, Dermime S, Behbehani K: Elevated expression of the toll like receptors 2 and 4 in obese individuals: its significance for obesity-induced inflammation. J Inflamm (Lond) 2012, 9:48.

48. Cadoudal $T$, Leroyer $S$, Reis AF, Tordjman J, Durant S, Fouque F, Collinet M, Quette J, Chauvet G, Beale E, Velho G, Antoine B, Benelli C, Forest C: Proposed involvement of adipocyte glyceroneogenesis and phosphoenolpyruvate carboxykinase in the metabolic syndrome. Biochimie 2005, 87:27-32.

49. Garaulet M, Hernandez-Morante JJ, Tebar FJ, Zamora S: Relation between degree of obesity and site-specific adipose tissue fatty acid composition in a Mediterranean population. Nutrition 2011, 27:170-6.
50. Dasu MR, Jialal I: Free fatty acids in the presence of high glucose amplify monocyte inflammation via Toll-like receptors. Am J Physiol Endocrinol Metab 2011, 300:E145-154.

51. Deo SH, Jenkins NT, Padilla J, Parrish AR, Fadel PJ: Norepinephrine increases NADPH oxidase-derived superoxide in human peripheral blood mononuclear cells via a- adrenergic receptors. Am J Physiol Regul Integr Comp Physiol 2013, 305:R11.

doi:10.1186/s12950-014-0039-y

Cite this article as: De Loera-Rodriguez et al:: Over-expression of TLR4CD14, pro-inflammatory cytokines, metabolic markers and NEFAs in obese non-diabetic Mexicans. Journal of Inflammation 2014 11:39.

\section{Submit your next manuscript to BioMed Central and take full advantage of:}

- Convenient online submission

- Thorough peer review

- No space constraints or color figure charges

- Immediate publication on acceptance

- Inclusion in PubMed, CAS, Scopus and Google Scholar

- Research which is freely available for redistribution

Submit your manuscript at www.biomedcentral.com/submit
C BioMed Central 